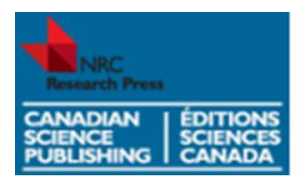

Canadian Journal of

Fisheries and Aquatic Sciences

Journal canadienne des

sciences halieutiques et

aquatiques

\title{
Genetic risks of supplementing trout populations with native stocks: a simulation case study from current Pyrenean populations
}

\begin{tabular}{|r|l|}
\hline Journal: & Canadian Journal of Fisheries and Aquatic Sciences \\
\hline Manuscript ID: & cjfas-2013-0362.R3 \\
\hline Manuscript Type: & Article \\
\hline Complete List of Authors: & $\begin{array}{l}\text { Fernandez-Cebrian, Raquel; Universitat de Girona, Biology } \\
\text { Araguas, Rosa Maria; Universitat de Girona, Biology } \\
\text { Sanz, Nuria; Universitat de Girona, Biology } \\
\text { García-Marín, Jose-Luis; Universitat de Girona, Biology }\end{array}$ \\
\hline Keyword: & $\begin{array}{l}\text { RECREATIONAL FISHERIES < General, GENETIC RESOURCES < General, } \\
\text { FRESHWATER FISHERIES < General, FISHERY MANAGEMENT < General, } \\
\text { CONSERVATION < General }\end{array}$ \\
\hline & \\
\hline
\end{tabular}

SCHOLARONE ${ }^{\text {Ix }}$

Manuscripts 
March-2014

3

4

5 Genetic risks of supplementing trout populations with native stocks: a simulation case study from current Pyrenean populations

GARCIA-MARIN Jose Luis *

14 LIG-UdG, Departament de Biologia, Facultat de Ciències, Universitat de Girona.

15 Campus Montilivi, 17071 Girona (Spain).

16

17 Keywords: Conservation genetics; Effective population size; Fisheries management;

18 Genetic diversity; Native stocks; Population structure

19

$20 *$ Corresponding author

21 Tel: +34 972418961

22 Fax: +34 972418150

23

$24 \quad$ Email: joseluis.garcia@udg.edu 


\section{Abstract}

26 The risks of supplementation must be examined to assess the genetic effects to native

27 wild populations before full implementation or exclusion of programs that involve

28 captive breeding and release. Real genetic data can be applied to simulations of genetic

29 changes in populations of interest, and subsequently used in risk assessment. Ancestral

30 Mediterranean brown trout lineages exhibit complex population structure among native

31 populations. Genetically divergent Atlantic stocks were maintained and released in the

32 Mediterranean rivers as recreational fish, which resulted in hybridization and

33 introgression with local populations. Therefore we designed a new supplementation

34 program based on native stocks, and evaluated the genetic risks associated with

35 releasing native fish in recreational fisheries. Our simulation was delimited by the

36 observed population genetic structure, and available hatchery facilities in the study

37 region. Supplementation with native stocks maintained estimates of gene diversity

38 indexes $\left(H_{T}, H_{S}\right.$ and $\left.G_{S T}\right)$. However, simulations indicated that long-term

39 supplementation significantly reduced genetic diversity among locations due to a

40 homogenizing effect of populations along each management unit. Therefore, such

41 reinforcements compromised the conservation of local genetic variation. Nevertheless,

42 replacement of current foreign with native stocks can be an important step towards

43 promoting the value of preserving local diversity among anglers. 


\section{Introduction}

45 Freshwater fish are among the most endangered species groups due to various

46 anthropogenic impacts, including habitat fragmentation and contamination, and water

47 exploitation and diversion (Freyhof and Brooks 2011). In addition, several freshwater

48 fish species have exhibited notable declines in recent decades from exotic species

49 introductions, overfishing, and/or release of non-native stocks (Cowx and Gerdeaux

50 2004). In temperate and cold river basins, salmonids have experienced declines due to

51 each of these threats on native freshwater biodiversity (Lewin et al. 2006; Naish et al.

52 2007), and on-going climate change has increased the vulnerability and endangered

53 status of salmonid species worldwide (e.g. Hari et al. 2006; Almodovar et al. 2012; Vera

54 et al. 2013). In addition to habitat recovery, several other strategies have been suggested

55 to improve local degraded populations. Extensive release of hatchery cultured fish to

56 enhance recreational opportunities has been widely applied, and supported by anglers

57 (Brown and Day 2002; Arlinghaus and Mehner 2005; Cowx et al. 2010). Despite the

58 widespread biological concerns of applying supplementation practices from hatchery-

59 reared fish to restore wild populations (Laikre and Ryman 1996; Lewin et al. 2006;

60 Naish et al. 2007; Araki and Schmid 2010), these practices continue; and anglers show a

61 positive response by increasing their fishing efforts soon after fish are released (e.g.

62 Baer et al. 2007), which subsequently promotes revenues to local economies

63 (Arlinghaus et al. 2002).

65 In European basins, brown trout are an integral target for a socio-economically

66 important recreational fishery (Elliot 1989). The economic value of the fishery

67 mandates the development of management strategies focused on achieving and

68 maintaining the delicate balance between exploitation and conservation of the resource 
69 (Araguas et al. 2009; Arlinghaus et al. 2010; Cowx and Van Anrooy 2010). Due to a

70 reduction in the abundance of catchable trout, anglers perceived efforts to reinforce

71 populations as a positive management objective (Arlinghaus and Mehner 2005). Such

72 circumstances also promoted supplementation initiatives among fisheries managers,

73 because recreational fisheries were traditionally managed based on the quality of the

74 fishing experience (Cowx and Gerdeaux 2004), and trout anglers associated quality with

75 catch quantity, and satisfaction followed (Arlinghaus and Mehner 2005). However,

76 management decisions based on anglers' perception could perpetuate stocking as a

77 panacea to maintain both, sustained fishery and the anglers' satisfaction, but at the risk

78 of replacing local fish diversity by hatchery stocks (van Poorten et al. 2011).

79 Mediterranean brown trout populations have been extensively supplemented with

80 North-eastern Atlantic hatchery stocks (hereafter, foreign stocks), resulting in

81 introgressed populations, and homogenization among wild populations (Poteaux et al.

82 1999; Marzano et al. 2003; Jug et al. 2005; Sanz et al. 2006; Apostolidis et al. 2008).

83 For example, Araguas et al. (2004) reported extensive foreign stock releases

84 compromised the genetic integrity and differentiation among native trout populations in

85 eastern Pyrenean rivers. In this region, up to 8 million fish were released in year 1995,

86 but later hatchery releases lowered and have been stabilized in recent times to 2 million

87 fish per year (Araguas et al. 2008). Because local salmonid populations often exhibit a

88 fitness advantage relative to foreign populations (Fraser et al. 2011; Perrier et al. 2013),

89 supplementation with foreign stocks is likely to reduce the mean population fitness in

90 recipient locations due to outbreeding depression and maladaptation of released fish

91 (Rhymer and Simberloff 1996, Baskett et al. 2013). Studies on the adaptive value of

92 local brown trout differences remain scarce, and not all phenotypic traits respond

93 similarly. For example, Jensen et al. (2008a) reported local adaptive variation for length 
94 at hatching, and length at first feeding among four Danish trout populations within close

95 geographic proximity. However, adaptive evidence for distinct hatching and survival

96 times was not detected among five brown trout populations in the Swiss Rhine Basin

97 (Stelkens et al. 2012). Nevertheless, a precautionary approach in conservation and

98 fisheries management mandates the preservation of local types, at least until clear

99 scientific evidence is collected to assess the biological significance of local differences

100 (e.g. FAO 1995).

101

102 European brown trout have several evolutionary lineages (revised in Kottelat and

103 Freyhoff 2007). The Atlantic one (now considered as Salmo trutta sensu stricto in IUCN

104 red list) was native in the Atlantic river basins northward from the Pyrenees. Several

105 morphological and genetically distinct Mediterranean lineages have been described (e.g.

106 S.rhodanensis, S.cettii, S.macrostigma), and some of them are now identified as

107 threatened species in the IUCN red list (Freyhoff and Brooks 2011). However, a

108 taxonomic revision of the trout types inhabiting Mediterranean Iberian rivers is still

109 lacking; despite they could represent several unnamed species (Kottelat and Freyhoff

110 2007). As a result, the Spanish inland fisheries agencies consider all trout populations in

111 Spain as S.trutta, according with former taxonomic studies (Lelek 1980). However,

112 since the 1980s, the Autonomous Government of Catalonia, as well as other regional

113 administrations, recognized declines in endemic trout biodiversity for the region; and

114 since 1987 introduced management measures to recover native populations. These

115 measures included an increase in length requirement for catchable fish from 18 to 22

$116 \mathrm{~cm}$, a reduction in hatchery releases, which are now banned in some upstream stretches

117 declared as genetic refuge locations to protect native gene pools, and a change to catch

118 and release management in some previously fished areas (Araguas et al. 2009). 
119 However, such restrictive measures typically received low angler support (Arlinghaus

120 and Mehner 2005). In addition, on-going assessments indicated that establishment of

121 genetic refuge did not result in a significant decrease in foreign stock alleles in the

122 Mediterranean Spanish and French wild populations (Araguas et al. 2008, 2009;

123 Caudron et al. 2011, 2012). Therefore, complementary active measures, including non-

124 native fish removal, supplementation with local native breeding stocks, and/or

125 translocation of wild native individuals were required to mitigate the genetic effects of

126 past releases with foreign fish (Caudron et al. 2012; Vera et al. 2013).

128 Hatchery strains derived from regional or local sources (hereafter, native stocks) have

129 been used to reinforce wild fish populations when conservation and fisheries

130 management goals were in common, because these stocks preclude damage to local

131 populations. For example, increased production with limited ecological and genetic

132 effects was observed in Hamma Hamma River steelhead (Oncorhynchus mykiss)

133 populations following supplemental stocking (Berejikian et al. 2008; Van Doornik et al.

134 2010). Hess et al. (2012) detected minimal negative impacts on fitness in a Chinook

135 salmon (O. tshawytscha) population in the Columbia River enhanced with supportive

136 captive breeding. Native stock reinforcement following habitat recovery is an accepted

137 measure within the European Inland Fisheries Advisory Commission (EIFAC) code of

138 practice for recreational fisheries (FAO 2008). Nevertheless, released fish from native

139 stocks and their wild progeny often exhibited decreased performance compared to wild

140 populations (reviewed in Araki et al 2008). For instance, Christie et al (2012) reported

141 genetic changes in the steelhead (O.mykiss) induced during a single generation of

142 hatchery culture resulting in maladaptation to the wild. Consequently more empirical

143 data is needed to evaluate the genetic and fitness effects of supplementation from native 
144 stocks (Naish et al 2007; Fraser 2008; Araki and Schmid 2010).

145

146 The risks inherent with a supplementation program involving captive stocks must be

147 carefully assessed prior to implementation of the program with native populations

148 (Naish et al. 2007; FAO 2008). Theoretical studies demonstrated reduced $\mathrm{Ne}$ and fitness

149 of wild populations following supportive breeding (Wang and Ryman 2001; Ford

150 2002), and a decline in local populations following long-term supplementation by native

151 domestic stocks (Satake and Araki 2012). The effect occurred through density-

152 dependent overcompensation during recruitment, resulting in fewer wild fish recruits.

153 Simulations from real genetic data, augment these theoretical population genetics

154 approaches (Hoban et al. 2012), which facilitated assessments of genetic changes in

155 populations of interest (e.g. Perrier et al 2013).

157 In the present study, we assess patterns of genetic diversity within and among

158 populations at 13 sampling locations along four river basins in the Pyrenean Mountains

159 as a basic pre-requisite to design a regional native hatchery stocks program. We

160 subsequently simulated a supplementation program that involved replacement of foreign

161 by native trout stocks using the observed population structure to select source locations,

162 while integrating the existing regional hatchery facilities and hatchery personal

163 expertise. We assessed the long-term genetic effects of the releases, including the target

164 population gene pools but also the population structure at the intra- and inter-basin

165 levels. Finally, we discussed the social and economic benefits of the results relative to

166 regional trout fisheries.

167

168 Materials and methods 
River network, sampled locations and estimates of genetic diversity

170 In the Spanish eastern Pyrenees, the river network is organized into two major units for

171 water supply and hydroelectric production, which includes the Ebro River basin and the

172 coastal rivers. The Ebro basin includes the easternmost Segre River drainage, composed

173 of the mainstem, and its tributaries the Noguera Pallaresa River $\left(2820.1 \mathrm{~km}^{2}\right.$ drainage

174 surface), and the Noguera Ribagorzana River (2045.6 $\mathrm{km}^{2}$ drainage surface). The Segre

175 basin supports the most preserved native populations of Mediterranean brown trout in

176 the Iberian Peninsula (Sanz et al. 2002). The largest coastal rivers are the Llobregat

$177\left(4948.3 \mathrm{~km}^{2}\right)$ and Ter $\left(3010.5 \mathrm{~km}^{2}\right)$ Rivers. Trout populations only inhabit the

178 headstreams of these rivers, with trout habitats more abundant in the Ter River, with

179 headstreams up to $2000 \mathrm{~m}$ a.s.1., where the Llobregat are below $1300 \mathrm{~m}$ a.s.1.

180

181 A total of 854 wild brown trout were collected during summer 2006 by electro-fishing

182 at 13 localities along the Noguera Pallaresa, Noguera Ribagorzana, Llobregat, and Ter

183 River basins (Table 1, Fig. 1) to assess patterns of genetic diversity within and among

184 Pyrenean populations. Each fish was anesthetized with tricaine methane-sulphonate

185 (MS-222) to biopsy a piece of the adipose fin. The sample was stored in an eppendorf

186 tube containing $96 \%$ ethanol and transported to the laboratory until DNA extraction. In

187 the field, the fork length of each fish was measured (to the nearest $0.5 \mathrm{~cm}$ ) to estimate

188 fish age $(0+, 1+, 2+, 3+$, and older fish) based on FISAT II software (Gayanilo et al.

189 2005) modal progression analysis and length-age relationships provided by Rocaspana

190 et al. (2006) for Pyrenean trout populations. Once recovered from anaesthesia, fish were

191 returned to the streams alive. We also analysed 96 fish from the 2003-year cohort of the

192 foreign stock at Bagà hatchery (HAT1, see Fig1) used to reinforce Pyrenean brown

193 trout populations in the region. We only analysed fish from this hatchery because trout 
194 culture at HAT2 is discontinued when trout production at HAT1 is enough to

195 supplement regional fisheries. Only when an increased hatchery production is required,

196 HAT2 receives fish from HAT1 to regenerate a new stock.

197

198 Genomic DNA was extracted from fin tissues using a proteinase K-Chelex extraction

199 protocol to assess genotypes for nine polymorphic microsatellite loci (Str15, Str73,

200 Str591INRA, Ssa85, Ssa408, SsHaeIII14.20, SsoSL417, SsoSL438, and SSsp2213) as

201 described by Sanz et al. (2009). MICRO-CHECKER 2.2.1 (Van Oosterhout et al. 2004)

202 revised microsatellite genotypes to test large allele dropout and null alleles.

203 Conformance of genotype distributions with Hardy-Weinberg expectations were tested

204 by exact probability tests (Guo and Thompson 1992) using the computer package

205 GENEPOP 3.3 (Raymond and Rousset 1995). For each location, the minimum number

206 of homogenous units $(K=1,2$, and 3$)$ was determined using the Bayesian Markov

207 Chain Monte Carlo (MCMC) approach in STRUCTURE 2.3.3 (Pritchard et al. 2000) as

208 indicated in Sanz et al. (2009). FSTAT2.9.3 software (Goudet 1995) was used to

209 summarize genetic diversity within samples as follows: mean unbiased expected

210 heterozygosity $\left(H_{E}\right)$, mean direct count heterozygosity $\left(H_{O}\right)$, and average allele richness

211 per locus $\left(A_{R}\right)$. To measure the level of current foreign stock introgression in each wild

212 location, we estimated the average proportion of foreign stock ancestry $(q)$ following

213 Sanz et al. (2009), however Araguas et al. (2008) already reported estimates for 10 of

214 these locations based on $\mathrm{LDH}-\mathrm{C}^{*}$ locus polymorphisms. Effective population size $(\mathrm{Ne})$

215 at each study location was estimated using linkage disequilibrium between loci in the

216 LDNe 1.31 program (Waples and Do 2008). Ne was estimated by removing rare alleles

217 with frequency less than 0.02 , due to a sample size of less than 50 fish in some study

218 locations. The LDNe method assumes discrete generations, which are not the case in 
219 brown trout; but the method roughly estimates $N e$ when the number of sampled cohorts

220 approximates the suspected generation time (Waples and Do 2010). At our study

221 locations, three cohorts $(0+, 1+$, and $2+$, see results $)$ were the most abundant, as

222 similarly reported in the Iberian Peninsula (Lobón-Cervia et al. 1986; Nicola et al. 2008;

223 Parra et al. 2009), suggesting generation lengths between 2-3 y for these trout

224 populations. Additional confidence on estimated $\mathrm{Ne}$ from our locations resulted from

225 genetic stability reported among five consecutive cohorts (year 1998 to 2002) studied in

226 an earlier work in the Vallfarrera stream (Vera et al. 2010).

227

228

Population structure

229 Genetic divergence between locations was examined using a matrix of pairwise genetic

230 differentiation, $F_{S T}$ (Weir and Cockerham 1984), and its significance (based on 1000

231 permutations) in FSTAT. Patterns of genetic diversity within and among the study river

232 basins were quantified by gene diversity analyses (Nei 1987) using FSTAT and

233 Analysis of Molecular Variance (AMOVA) using Arlequin 3.5.1.3 (Excoffier and

234 Lischer 2010). Hierarchical levels followed hydrogeographical criteria within $\left(F_{S C}\right)$ and

235 among $\left(F_{C T}\right)$ basins or tributaries, and involved an analysis spanning the entire study

236 region, and separate analyses for each river basin. Additionally, the pairwise genetic

237 distance matrix among samples ( $D_{a}$, Nei 1987) computed using MSA 4.05 (Dieringer

238 and Schlötterer 2003) was used to generate a multidimensional scaling (MDS) using

239 SPSS program to depict genetic similarity between study locations. Finally, we

240 examined the most likely number of genetically homogeneous groups ( $K=1$ to 13$)$ in

241 the study region from the Bayesian method implemented in STRUCTURE 2.3.3

242 following Evanno et al. (2005) after 20 replicate STRUCTURE runs for each $K$ value. 
243 Each run used a burn-in of 10000 iterations, a run length of 10000 iterations, and all

244 other parameters set to default model.

245

246 Design of the native stocks

247 The current foreign hatchery stock originated from central European trout, and regional

248 fishery management could require its replacement with native stocks in the future.

249 However, we should keep in mind that despite the stock origin, the current normative

250 framework involving hatchery trout stocks in the study region serves to support

251 recreational fisheries, and not conservation genetics goals. In addition, legislation on

252 other water uses (e.g. industrial, agricultural, and domestic consumption, or

253 hydroelectric production) often takes prevalence over recreational fisheries. The

254 Environmental Services of the Autonomous Government of Catalonian manage trout

255 populations in all the regional basins. However, water supplies and hydroelectric

256 production in the Ebro River basin are under the jurisdiction of the C.H.E.

257 (Confederación Hidrográfica del Ebro), a Spanish State agency; while in the coastal

258 rivers are jurisdiction of the A.C.A (Agència Catalana de l'Aigua), an agency of the

259 Autonomous Government of Catalonian. Because our genetic results suggest "basin" as

260 a primary source for population structure, we focused on "basin" (Ribagorzana,

261 Pallaresa, Llobregat and Ter River basins) as a work unit, which also facilitates the

262 administrative collaboration between the environmental and water agencies. The

263 location (see Fig.1) and facilities of the two regional hatcheries should easily

264 accommodate and separately manage several stocks, despite their previous expertise,

265 which focused on one stock.

266

267 For the simulation, we first selected a source location for each river basin, which was a 
268 challenging task (Allendorf and Ryman 1987; Griffith et al. 2009; Laikre et al. 2010).

269 The selection criteria involved Hardy-Weinberg and gametic equilibria; and low

270 impacts involved with on-going hatchery release of the foreign stock (see results in

271 Table 1). Furthermore, genetic refuge locations were preferred (Araguas et al. 2008).

272 We finally prioritized sources located on river drainage mainstems, because brown trout

273 in mainstem populations were typically larger than in small tributaries (Parra et al.

274 2009), which can increase offspring abundance in the first generation at hatchery

275 facilities, i.e. large trout should have increased fecundity (Lobón-Cerviá et al. 1997).

276 Abundant progeny from as many parents as possible might facilitate further F1

277 manipulation to prevent undesirable genetic diversity losses in hatchery stocks (Araki et

278 al. 2008, Fraser 2008). A large amount of stock diversity was also desirable to prevent

279 further changes by selection and domestication (Fraser 2008; Araki and Schmid 2010).

280 Because of the high amount of foreign stock introgression in the single location studied

281 at the Llobregat River basin we decided to join this basin to the Ter River for the

282 simulated supplementation program as a single management unit for all coastal basins.

283 Subsequently, three captive native stocks were simulated, one to stock the Noguera

284 Ribagorzana River, one the Noguera Pallaresa, and one to stock the coastal basins.

285 According with results on genetic structure, the simulated native stocks supplementation

286 program allowed assessment of genetic effects at intra and inter basins scales covering

287 aspects as: (i) maintenance of the population structure at regional scale, (ii) preservation

288 of local singularities, and (iii) recovery of native gene pools in heavily introgressed

289 locations with foreign alleles. In this later case, at Filià location we simulated the

290 recovery using a native stock derived from a location in the same river, but at the

291 Riutort location by using an stock originated from distinct river.

292 
294 Our simulation evaluated the long-term effects (100 generations) on genetic population

295 structure of a potential supplementation program using the three native stocks

296 characterized above. Initially, a $\mathrm{Ne}$ of 100 was assumed for each location, well in the

297 range of estimated brown trout $\mathrm{Ne}$ at each study location (see results in Table 1). The

298 supplementation effort was adjusted to accept the one-migrant-per-generation (OMPG)

299 rule, considered enough to maintain polymorphism and heterozygosity levels within

300 wild locations, while facilitating divergence (Mills and Allendorf 1996). This level of

301 hatchery introgression per generation was consistent with previous estimates in the

302 study area resulting from release of foreign hatchery fish (1 to 5\%, Araguas et al. 2004).

303 For each study location using HYBRIDLAB software (Nielsen et al. 2006), we first

304 simulated samples of 100 individuals at generation 0 from current allele frequencies. In

305 addition, for each native stock we simulated 1000 individuals from the current

306 genotypes representing the source locations. Although a Ne size of 1000 fish for stock

307 might be perceived as unrealistic due to the abundant evidence for genetic changes in

308 salmonid hatchery stocks (Naish et al. 2007; Araki and Schmid 2010), it allowed us to

309 address genetic change in wild populations resulting from fish released from native

310 stocks kept genetically similar to the native source. In addition, this approach might also

311 have utility in evaluating genetic change induced by repetitive supportive breeding from

312 a few local sources.

314 All wild and stocked fish simulated at generation 0 were aged as adults, and randomly

315 sexed as male or female. Input data were subsequently converted in an FSTAT format

316 file used for simulations in NEMO v2.2 software (Guillaume and Rougemont 2006). In

317 each management unit (Noguera Pallaresa, Noguera Ribagorzana and Coastal basins), 
318 and in each of their wild population, we simulated 100 generations of native stock

319 reinforcement by setting the local immigration rate $(\mathrm{m})$ from the assigned stock to 0.01

320 using the NEMO software "breed-disperse" life cycle event. Ne for wild and stock

321 populations was maintained each generation at 100 and 1000 individuals, respectively.

322 All loci assorted independently (recombination rate adjusted to 0.5), and simulated

323 genotypes at each generation were stored for further analyses.

325 The above reinforcement scenario was compared with simulated management in the

326 absence of supplementation, and drift as a single evolutionary force during 100

327 generations based on negligible dispersal and gene flow reported between resident trout

328 populations even at hydrogeographic distances of a few kilometres (Knouft and Spotila

329 2002; Vera et al. 2010; Vollestad et al. 2012). Gene pool evolution within each location

330 was subsequently simulated as indicated above for the supplementation program, but

331 local immigration from the assigned stock was not permitted $(\mathrm{m}=0)$. Additional

332 simulations were performed for $\mathrm{Ne}$ of 50, and 1000 fish in wild populations for both

333 scenarios, with and without supplementation with native stocks. Finally, three

334 additional data sets were simulated based on maintaining current foreign stock releases

335 into all wild locations ( $\mathrm{m}=0.01$ per generation), and respectively considering $\mathrm{Ne}$ of 50 ,

336100 , and 1000 fish. In summary, $3 \times 3$ (three scenarios $\mathrm{x}$ three $\mathrm{Ne}$ ) simulated genotype

337 data sets were collected.

339 Genetic diversity levels at Generation 0 and 100 for each location and scenario were

340 estimated using FSTAT. In all simulations, gene pool stability between generations 0

341 and 100 in each wild location, and in each simulated stock, was estimated by $F_{S T}$ values

342 (Weir and Cockerham 1984). Significance levels were obtained from 1000 permutation 
343 tests in FSTAT. Patterns of population structure among locations followed after 100

344 simulated generations, and for each scenario were estimated by gene diversity analyses

345 (FSTAT). The proportion of divergence between locations within (SC) and among (CT)

346 river basins was examined using hierarchical AMOVAs (Arlequin Software). In

347 addition, population relationships among locations in simulated scenarios (with and

348 without reinforcement) were depicted by nonparametric multidimensional scaling

349 (MDS) from the $D a$ genetic distance matrix between location pairs, as indicated above

350 in the study of captured wild samples. Furthermore, to assess local genetic changes in

351 scenarios with and without supplementation with native stocks, and $\mathrm{Ne}$ of 100 , we

352 estimated the remaining proportion of the simulated generation 0 and the contribution of

353 the native stock, both as $q$-values following Sanz et al. (2009) as indicated above for

354 estimating the current contribution of the foreign hatchery stock on wild locations. We

355 should note that the estimated native stock $q$-value associated with each location under

356 drift was not related to any effects of fish release, but to historical evolutionary

357 processes within and among basins, driving the current genetic divergence between

358 locations. The estimated native stock $q$-value under drift provides only a reference value

359 to compare with $q$-value obtained under reinforcement.

360

$361 \quad$ Results

362 Genetic diversity and population structure of wild populations

363 Brown trout populations at the study locations were short-lived, with a clear dominance

364 of age groups $0+$ to $2+$, with the exception of the Vallter location, where older fish ( $>$

$3652+$ ) were also abundant (Table 1). On average, $77.0 \%$ of fish sampled were in age

366 classes $0+$ to $2+$, and ranged from $55.4 \%$ in Vallter to $99.5 \%$ in Nuria. Genetic diversity

367 differed among locations (Table 1), with the highest variability exhibited in Filià 
$368\left(A_{R}=8.40, H_{E}=0.769\right)$, and the lowest variability in Vallter $\left(A_{R}=3.23, H_{E}=0.393\right)$.

369 Genetic variability in the current hatchery stock was also high $\left(A_{R}=7.78, H_{E}=0.682\right)$,

370 and some abundant allele variants detected in this foreign stock $(\operatorname{Str} 73 * 146$,

371 Str59IINRA*158, SsHaeIII14.20*312, SsHaeIII14.20*324, SsHaeIII14.20*322, and

372 SsoSL438*105) were rare in wild trout.

373

374 Following Bonferroni correction, genotype distributions at three study locations (Tor,

375 Erta, and Nuria) deviated from Hardy-Weinberg expectations due to homozygote excess

376 (supplementary Table S1). MICRO-CHECKER suggested the presence of null alleles in

377 the Nuria Str15INRA locus, and the Tor SsoSL417 locus. Nevertheless, evidence of null

378 alleles at these two loci was not detected at other study locations. In Nuria, Riutort, Tor,

379 Filià, Cavallers, and Erta, significant gametic disequilibria was observed after applying

380 a Bonferroni correction for multiple tests. High hatchery ancestry ( $q$-values) were

381 detected in fish sampled at Riutort and Filià ( 0.30 at both study locations) (Table 1$)$, but

382 in the other study locations the estimated hatchery ancestry for captured fish was below

$3835 \%(0.05)$. STRUCTURE results suggested two genetically distinct units presented in

384 Riutort, Filià, Nuria and Tor locations. The abundance of rare homozygotes for alleles

385 common among hatchery fish indicated recent releases in these streams responsible for

386 observed Hardy-Weinberg and gametic disequilibria. Estimated Ne ranged from 18.7 in

387 Filià to 293.0 in Ermita, and a larger indeterminate estimate in Ainet, i.e. 243.9 to $\alpha$.

388 Reduced $\mathrm{Ne}$ were related to locations with evidence for recent release of hatchery fish

$389 \quad(K=2$; Table 1$)$.

390

391 Significant pairwise differentiation was detected in all but one comparison, i.e. Ermita-

392 Palomera (Table 2). Despite high hatchery $q$-values observed in Riutort and Filià, all 
393 wild populations exhibited significant genetic differentiation from current hatchery

394 foreign stock $\left(F_{S T}\right.$ range 0.116-0.426). Hierarchical AMOVA results for the entire study

395 area reflected higher significant divergences within $(S C$ component $=86.14 \%$, Table 3$)$

396 than among basins $(C T$ component $=13.86 \%)$. Due to the increased number of study

397 locations in the Pallaresa and Ribagorzana basins, a hierarchical AMOVA was possible

398 for each of the two basins. In both basins, results showed increased differentiation

399 within compared to among tributaries. In the Pallaresa River $\left(G_{S T}=0.160\right)$, where the

400 two more hydrogeographically separated study locations were Palomera and Filià (91.6

$401 \mathrm{~km}$ ), only 23.35 per cent of the total differentiation was assigned to differences among

402 tributaries. In the Ribagorzana River, increased differentiation was observed among

403 locations $\left(G_{S T}=0.357\right)$, even though within this basin, $64.95 \%$ of the population

404 differentiation was assigned within tributaries. In this basin, the largest hydrogeographic

405 separation among study locations occurred between Conangles and Cavallers, $50.1 \mathrm{~km}$

406 apart.

407

408 STRUCTURE (Fig. 2) and MDS analyses based on $D_{a}$ distances (Fig. 3, 2006

409 collections) were largely congruent. Gene pools from study locations were grouped

410 following a hydrogeographic pattern (Ter, Pallaresa, and Ribagorzana), however two

411 outlier samples from different basins were grouped together, i.e. Manyanet and Erta,

412 and a fifth group comprised the high hatchery ancestry locations Riutort and Filià ( $q$ -

413 value $=0.300$, see Table 1$)$.

414

415 Simulated long-term effects of supplementation with native stocks

416 None of the study locations had the complete requirements to be an ideal source

417 location for native stocks (Table 1). The selected source locations for simulated native 
418 stocks were then determined as follows: Ermita for the Noguera Pallaresa basin due to

419 the location inclusion as a genetic refuge, reduced average hatchery ancestry, and lack

420 of evidence for Hardy-Weinberg or gametic disequilibria; Conangles for the Noguera

421 Ribagorzana River due to its location in a genetic refuge area in the river mainstem, and

422 Vallter for Coastal basins due to low incidence of hatchery releases, the largest $\mathrm{Ne}$

423 estimate among the three study locations in the coastal management unit, and inclusion

424 as a genetic refuge. Permutation tests in FSTAT indicated that average genetic diversity

425 from source locations (see Table 3) was not significantly different from the average

426 diversity at other study locations $(P>0.05)$, and divergence among source locations

$427\left(G_{S T}\right)$ resulted in the observed population differentiation among the eastern Pyrenean

428 trout populations $(P>0.05)$. Despite $N e$ for stocks fixed at 1000 fish, small but

429 significant $(P<0.05) F_{S T}$ value between generation 0 and 100 was observed in all

430 simulated stocks (including the foreign one). However, these allelic changes did not

431 significantly modify stock diversity levels (allele richness and gene diversity) as

432 indicated by FSTAT permutation tests.

433

434 Following 100 generations, simulated genetic drift in wild populations of 100

435 individuals caused loss in genetic diversity, and significant allele frequency changes $(P$

$436<0.001)$ at all locations, indicated by $F_{S T}$ coefficients (Table 4). Simulations showed

437 supplementation with native stocks maintained levels of diversity (heterozygosity and

438 allele richness) at most locations, but again, significant $F_{S T}$ values were detected $(P<$

439 0.001), even at the native stock source location. However, genetic changes resulting

440 from supplementation with native stocks were generally less severe (decreased $F_{S T}$

441 value) than alterations observed from maintaining supplementation with the current

442 exogenous stock (Table 4). Short time supplementation with native stocks (10 
443 generations) did not significantly alter diversity patterns within and among locations

444 (Table 3, Fig. 3 G10 N100). Estimates of ancestries in the populations following 100

445 generations in scenarios with and without (drift) supplementation with native stocks

446 added information on genetic changes occurred in each location (Table 5). Despite

447 losses in genetic diversity for simulations involving genetic drift, the estimate remaining

448 ancestry for the local original (generation 0 ) gene pool was close to 1.0 at each location,

449 and the estimated native stock ancestry was only high for the respective source location

450 except in Palomera. Here, the estimated native stock ancestry was high because of its

451 current genetic similarity with the Ermita trout, which was used as source for the

452 simulated native stocks in the Noguera Pallaresa River basin $\left(F_{S T}=0.003\right.$; Table 2$)$.

453 However in all basins, supplementation with native stock produced declines of the

454 original gene pool ancestry for all locations, particularly in locations currently showing

455 large genetic divergence from the source population (Tor and Manyanet in the Noguera

456 Pallaresa basin; Cavallers, Nicolau, and Erta in the Ribagorzana basin, and Riutort in

457 the coastal basins). As expected, these declines were related to increased estimates in

458 native stock ancestry. Altogether indicated that supplementation with native stocks was

459 efficiently eroding local gene pools.

460

461 In simulations of $\mathrm{Ne}$ of 100 individuals, FSTAT comparisons confirmed reduced

462 average allele richness within locations in the simulated scenario with and without

463 (drift) native stocks supplementation (Table 3). The simulation without supplementation

464 maintained total diversity $\left(H_{T}\right)$ in the region by significantly reducing local diversity

$465\left(H_{S}\right)$, and increasing divergence $\left(G_{S T}\right)$ among locations. The native stocks

466 supplementation program showed reduced effects on gene diversity indices $\left(H_{T}, H_{S}\right.$ and

$467 G_{S T}$, as significant changes were not detected with current estimates. In addition, 
468 continued release of foreign stock did not result in significant changes in allele richness

469 and gene diversity indices. However, hierarchical AMOVAs indicated releases from

470 foreign stock into all native population locations nearly eliminated the genetic

471 distinction among management units (CT component close to 0; Table 3). Hierarchical

472 AMOVAs also showed that without supplementation, drift alone was not sufficient to

473 completely erode genetic differences within (SC component) and among (CT

474 component) into the management units. Nevertheless, supplementation with native

475 stocks resulted in increased genetic homogenization of populations within management

476 units (strong reduction in the SC component). MDS results from $D a$ genetic distance

477 matrices between locations (Fig. 3) clearly depicted all changes in population structure

478 in the study area resulting from supplementation with exogenous and native stocks.

479 Consequently, following long-term supplementation by native stocks, populations were

480 clustered based on management units, while maintaining releases from a common

481 foreign stock, resulted in genetic relationships among populations from distinct

482 management units.

483

484 In simulations involving population sizes of 50 fish, the effects of drift were evidenced

485 by reduced average allele richness and increased divergence among locations under all

486 simulation scenarios (Table 3), however a large "among management units" component

487 (CT) was obtained from supplementing with native stocks (Fig. 3). This diversity

488 component (CT) was not preserved in the other two scenarios (with or without

489 supplementation with the foreign stock). Nevertheless, simulations with population

490 sizes of 1000 fish exhibited decreased genetic changes in gene diversity and hierarchical

491 population structure under the drift scenario compared to any supplementation program

492 (Table 3). 
494 Discussion

495 Current wild population status

496 Brown trout in the eastern Pyrenean rivers showed levels of diversity at microsatellite

497 loci well within the range detected in Mediterranean populations from other countries

498 (Jug et al. 2005; Apostolidis et al. 2008). Populations showing the greatest genetic

499 impacts following releases of the Atlantic foreign stock (Riutort and Filià locations,

500 Table 1) also exhibited the highest estimates of heterozygosity. Recent foreign stock

501 releases remained common evidenced by the two breeding units detected at four study

502 locations (Nuria, Riutort, Tor, and Filià), which were supported by high estimates of

503 hatchery ancestry or Hardy-Weinberg and gametic disequilibria. Despite estimated

504 introgression rates below 5\% from all study locations, with the exception of Riutort and

505 Filià, wider geographical surveys suggested average introgression rates from Atlantic

506 foreign stocks exceeded 10\% in eastern Iberian trout populations (Sanz et al. 2002;

507 Aparicio et al. 2005; Almodovar et al. 2006). Recent releases likely contributed to the

508 small $\mathrm{Ne}$ estimated in Tor and Filià, as expected from theoretical predictions on

509 hatchery releases and long-term supportive breeding programs (Ryman and Laikre

510 1991; Wang and Ryman 2001, Waples and England 2011). However, a large amount of

511 native genetic diversity was still preserved within the eastern Pyrenean rivers, where

512 native brown trout remained morphologically distinct from hatchery fish (Aparicio et al.

513 2005).

514

$515 N e$ estimates suggested adequately self-sustained trout populations in some locations,

516 including Ter, Palomera, Ermita, Ainet, Manyanet, Nicolau, and Erta. In the Iberian

517 Peninsula, age at maturity for brown trout is between $1+$ and $2+$ for females, and $2+$ to 
$5183+$ for males (Lobón-Cerviá et al. 1986; Parra et al. 2009). The adult fish older than 2+

519 at time of capture represented less than $40 \%$ in all study locations with the exception of

520 Ter. In addition, fish available for angling should be even less abundant, because at the

521 study locations, the oldest fish $(>3+)$ reach catchable length $(22 \mathrm{~cm})$ i.e. in Iberian

522 rivers (Lobón-Cerviá et al. 1986; Rocaspana et al. 2006; Parra et al. 2009). A decrease

523 in catchable fish $(<10 \%)$ abundance is common among fished trout populations

524 compared with increased abundance in unfished stretches (Almodovar and Nicola

525 2004). Nevertheless, environmental factors and anthropogenic-mediated perturbations,

526 in addition to angling contribute to reductions in catchable trout throughout Spanish

527 rivers (Almodovar and Nicola 1999; Nicola et al. 2009; Ayllón et al. 2012), including

528 Pyrenean waters (Garcia de Jalon et al. 1988, 1996; Alonso et al. 2011). Cumulatively,

529 these factors promote social support for supplementation practices.

530

531 Genetic effects of the supplementation with native stock

532 Our results indicated that following short-term supplementation, sporadic supportive

533 breeding programs from local sources would not markedly change the gene pools of the

534 supplemented populations. In addition, as Caudron et al. $(2011,2012)$ reported in

535 French brown trout populations following supportive breeding programs, simulations

536 predicted recovery of native diversity in the Filià and Riutort populations highly

537 impacted by current releases of a foreign hatchery stock. In the French streams, trout

538 densities increased 20 - to 55 -fold, and the majority of juvenile trout (78-89\%) were

539 first-generation descendants of released trout. However, recovering native alleles in

540 these previously highly introgressed populations might not restore native local ancestry,

541 but result in genetic swamping of the local populations along the management unit by

542 the native stock gene pool. Swamping was particularly relevant in locations reinforced 
543 with a native stock originated from a source in other river basin as Riutort in our

544 simulations; in this location a notorious reduction of the original local ancestry was

545 observed. Within management units, such an effect was even more evident in

546 genetically unique native populations, as Manyanet and Erta in our study. In these

547 outlier populations, the native local gene pool were reduced following long-term

548 supplementation, while a notable increase in the estimate native stock ancestry was

549 observed. The expected result following long-term supplementation with native stocks

550 was then a significant reduction in diversity among locations within management units.

551 However, in the study region, current genetic differentiation was related more with local

552 divergence within rather than isolation between basins. Similar results have already

553 been observed in the wild; for example, populations of Coho salmon (Oncorhynchus

554 kisutch) in the Puget Sound of Washington State that underwent extensive hatchery

555 propagation share more of their ancestry recently than they did historically (Eldridge et

556 al. 2009). Hansen et al. (2009) reported substantial local changes in Danish brown trout

557 populations following long-term supplementation with Danish stocks. Supportive

558 breeding efforts in French Mediterranean trout populations showed over short-term time

559 scales, the genetic and demographic effects were restricted to river stretches $2 \mathrm{~km}$

560 downstream from the release locations (Caudron et al. 2012), however other evidence

561 indicated expansion of hatchery genes by hybridized fish occurring over longer periods

562 of time following releases (García-Marín et al. 1998; Allendorf et al. 2004; Araguas et

563 al. 2008; Perrier et al. 2013).

565 Fishery managers should be aware that simply maintaining global estimates of gene

566 diversity indices $\left(H_{T}, H_{S}\right.$ and $\left.G_{S T}\right)$ does not insure conservation of local genetic

567 variation. For example, significant changes were not detected in diversity indices for 
568 supplementation simulations, either using current foreign or native stocks, despite losses

569 of native alleles in all locations. Therefore, native stocks do not mean local stocks, even

570 at short hydrogeographical distances. Increased genetic differentiation between

571 Pyrenean brown trout populations suggested isolated populations at hydrogeographical

572 separation of just a few kilometres. In fact, the only non-significant divergence detected

573 in the entire study was between Palomera and Ermita locations, $1.2 \mathrm{~km}$ apart along the

574 same mainstem of the Vallfarrera River. Hierarchical partitioning of genetic diversity

575 revealed another relevant source of divergence between tributaries in the same river

576 basin. For example, the Tor River sample was collected $6 \mathrm{~km}$ from the Ermita location

577 in a tributary of the Vallfarrera River, and the estimated $F_{S T}$ value between Tor and

578 Ermita samples was 0.175.

579

580 Selective forces

581 Our study was based on microsatellite loci, which are typically considered selective

582 neutral markers. However, there might be adaptive and selective processes modulating

583 and modifying our observations. First, we should consider the adaptive value of trout

584 genetic singularities in the Pyrenean locations. Certainly it remains to be demonstrated,

585 yet the observed divergences at microsatellite loci among these trout populations were

586 congruent with distinctions based on protein coding loci variation reported earlier by

587 Araguas et al. (2004). Local adaptation in salmonids occurs at several spatial scales

588 (from a few to thousands of kilometers), with local populations often manifesting a

589 fitness advantage over foreign populations (Fraser et al. 2011; Perrier et al. 2013). In

590 brown trout, selective processes have been detected at small spatial scales for loci

591 related to immune systems, i.e. MHC or TAP (Hansen et al. 2007; Jensen et al. 2008b;

592 Keller et al. 2011), but also at microsatellite loci linked to functional loci and QTLs 
593 (Meier et al. 2011). Therefore, the high divergence $\left(F_{S T}\right)$ observed between wild

594 Pyrenean populations could be related with local adaptation. In this sense, the

595 divergence observed among locations within each management unit is often as high as

596 values reported among wild locations and the current foreign stock, questioning whether

597 the choice of a single native source for each management unit would be a successful

598 management decision. Unfortunately, a supplementation program involving all

599 requested and necessary native stocks to preserve all local genetically differentiated

600 populations at the intra- and inter- basin levels currently appears unfeasible due to the

601 reduced infrastructure (two hatcheries), and high economic costs of maintaining several

602 native stocks.

603

604 Selective domestication induced by culture conditions is often detected in hatchery

605 stocks (Araki and Schmid 2010). Putative diversifying selection between wild

606 populations and hatchery trout stocks (e.g. Hansen et al. 2010) can result in additional

607 risk due to reduced average fitness of reinforced wild populations, even at low fitness

608 differences between wild and hatchery fish (weak selection), facilitated for instance by

609 reiterated immigration of wild fish into captive stock (Ford 2002). Surprisingly,

610 releasing hatchery stocks phenotypically differentiated from wild populations might

611 result in less harmful effects because the phenotype divergence could be associated with

612 traits maladaptive to wild conditions, and hence strong selective pressures purging

613 released fish before the reproductive season (Baskett and Waples 2012; Baskett et al.

614 2013). In the study territory, the current hatchery stock is phenotypically divergent from

615 wild populations (Aparicio et al. 2005), and its foreign origin and long-time

616 maintenance in captive conditions might result in maladaptation to wild conditions.

617 Based on the simulation results of Baskett et al. (2013), such maladaptation could 
618 justify the reduced estimates of hatchery introgression detected in Pyrenean trout

619 populations despite the long period of intensive releases (Sanz et al 2002, Aparicio et al

620 2005), and questions the suitability of replacing foreign stock by native. Nevertheless,

621 reduced impact of hatchery releases has been reported among North-European

622 populations phylogenetically close to source populations of our foreign stock (e.g.

623 Ruzzante et al. 2001).

625 Conclusions: management prospectives

626 Results of our simulations indicated that in wild populations comprised of an effective

627 population size of 100 individuals, genetic drift would result in significant changes in

628 the study basin gene pools during the next one hundred years. However, drift alone

629 might better conserve distinct populations among locations within management units.

630 Based on simulation predictions, an increase in effective population size to 1000

631 individuals decreased the likelihood of significant changes in the study basin gene

632 pools. In this case, within and among population changes were lower than those caused

633 by regional reinforcement policies. Such results suggested that habitat restoration to

634 insure large effective population sizes might be enough to protect native genetic

635 diversity. Sociological studies on German anglers indicated that limiting brown trout

636 management to improve or maintain good habitat quality would receive anglers'

637 support, primarily when catches were increased, and fishing experiences were positive

638 (Baer and Brinker 2010), but even then, a large proportion of anglers were not opposed

639 to supplementation practices (Arlinghaus and Mehner 2005). Therefore, avoiding

640 hatchery-releases might compromise angler support for further management measures.

641 In the eastern Pyrenean rivers, a combination of genetic refuges to protect native trout

642 diversity in some stretches, and stocking practices in other river sections undergoing 
643 intensive fishing efforts, has favoured restrictive measures in a per day bag and

644 increased minimum catchable size limits, and additional fishing river stretches

645 designated as catch-and-release areas (Araguas et al. 2009). In addition, the current

646 normative framework involving trout populations in the Spanish eastern Pyrenean

647 serves to support recreational fisheries, and anglers' societies are the key stakeholders

648 and one of the main lobbyists in decision-making on regulatory measures in the

649 Pyrenean river basin. Because of pending taxonomic revision, any distinct trout taxa

650 from the study region were not included in the most recent red list of European

651 freshwater fish (Freyhoff and Brooks 2011), limiting conservationists' arguments

652 against extensive hatchery trout releases and translocations.

654 Often criticized due to the conservation risks on remnant biodiversity (Laikre et al.

655 2010), hatchery stock supplementation is maintained as a traditional fisheries practice,

656 because it is perceived as a prophylactic measure for human induced damage, including

657 fisheries itself, on wild populations (Arlinghaus et al. 2002). From a put-and-take fish

658 stocking point of view, which is maintained in some eastern Pyrenean river stretches, it

659 may be irrelevant which stocks, foreign or native, are used for release. In fact, current

660 foreign hatchery stocks are well-adapted to hatcheries, and hatchery personnel have

661 sufficient expertise to generate large output to enhance regional trout fisheries.

662 However, compared with maintaining supplementation from foreign stock,

663 supplementation from native stocks might serve as a much better balance between the

664 social benefits of angling and biological damage to native diversity in the regional river

665 basins. Together with measures that limit native releases to locations of intensive

666 fishing that preclude the survival of released fish before the spawning season, the

667 replacement of current foreign with native trout stocks provides an important 
668 opportunity to promote the value of preserving local diversity among anglers, and with

669 the presently implemented genetic refuge policy, should be an additional step in the

670 albeit slow transition to a fisheries model focused on local self-sustaining trout

671 populations, and regional habitat management. Native stock development can stimulate

672 regional hatchery expertise and hatchery personnel to manage native fish, and facilitate

673 short-term supportive breeding programs to recover endangered native trout

674 populations.

675

676 Acknowledgements

677 The Spanish MCYT (currently MINECO) research project REN-2003-05931/GLO and

678 the Universitat of Girona research budget ASIGN2012/01 provided support for this

679 study. RFC was FPI fellow of the MCYT. We thank Dr. Fred M. Utter for revisions and

680 editing of an early draft of this manuscript. Dr. Joanna Schultz from WSR scientific

681 editing services revised the manuscript. In addition, we appreciate the contribution of

682 five anonymous reviewers on earlier versions of the manuscript.

683

684 References

685 Allendorf, F.W., and Ryman, N. 1987. Genetic management of hatchery stocks, in:

686 Ryman, N., Utter, F. (Eds.), Population genetics and Fishery management.

687 Washington Sea Grant Program, Univ. Washington Press, Seattle, pp 141-159.

688 Allendorf, F.W., Leary, R.F., Hitt, N.P., Knudsen, K.L., Lundquist, L.L., and Pruell, P.

689 2004. Intercrosses and the U.S. Endangered Species Act: Should Hybridized

690 Populations be Included as Westslope Cutthroat Trout? Conserv. Biol., 18,

$691 \quad 1203-1213$. 
692 Almodovar, A., and Nicola, G.G. 1999. Effects of a small hydropower station upon

693

694

695

696

697

698

699

700

701

702

703

704

705

706

707

708

709

710

711

712

713

714

715 brown trout Salmo trutta L. in the River Hoz Seca (Tagus basin, Spain) one year after regulation. Regul. Rivers, 15, 477-484.

Almodovar, A., and Nicola, G.G. 2004. Angling impact on conservation of Spanish stream-dwelling brown trout Salmo trutta. Fish. Manag. Ecol., 11, 173-182.

Almodóvar, A., Nicola, G.G., Elvira, B., and García-Marín, J.L. 2006. Introgression variability among Iberian Brown trout Evolutionary Significant Units: the influence of local management and environmental features. Freshw. Biol., 51, $1175-1187$.

Almodovar, A., Nicola, G.G., Ayllón, D., and Elvira, B. 2012. Global warming threatens the persistence of Mediterranean brown trout. Glob. Change Biol., 18, 1549-1560.

Alonso, C., García de Jalón, D., Álvarez, J., and Gortázar, J. 2011. A large-scale approach can help detect general processes driving the dynamics of brown trout populations in extensive areas. Ecol. Freshw. Fish, 20, 449-460.

Aparicio, E., García-Berthou, E. Araguas, R.M., Martínez, P., and García-Marín, J.L. 2005. Body pigmentation pattern to assess introgression by hatchery stocks in native Salmo trutta form Mediterranean streams. J. Fish Biol., 67, 931-949.

Apostolidis, A.P., Madeira, M.-J., Hansen, M.M., and Machordom, A. 2008. Genetic structure and demographic history of brown trout (Salmo trutta) populations from the southern Balkans. Freshw. Biol., 53,1555-1566.

Araguas, R.M., Sanz, N., Pla, C., and García-Marín, J.L. 2004. Breakdown of the brown trout evolutionary history due to hybridization between native and cultivated fish. J. Fish Biol., 65(A), 28-37. 
716 Araguas, R.M., Sanz, N., Fernández, R., Utter, F.M., Pla, C., and García-Marín, J.L.

717 2008. Genetic refuges for a self-sustained fishery: experience in wild brown

718 trout populations in the eastern Pyrenees. Ecol. Freshw. Fish, 17, 610-616.

719 Araguas, R.M., Sanz, N., Fernández, R., Utter, F.M., Pla, C., and García-Marín, J.L.

720 2009. Role of genetic Refuges in the Restoration of Native Gene pools of Brown

721 Trout. Conserv. Biol., 23, 871-878.

722 Araki, H., and Schmid, C. 2010. Is hatchery stocking a help or harm? Evidence,

723 limitations and future directions in ecological and genetic surveys. Aquaculture,

$324 \quad 308$ (Suppl. 1), S2-S11.

725 Araki, H., Barry A. Berejikian, B.A., Ford, M.J., and Blouin, M.S. 2008. Fitness of

726 hatchery-reared salmonids in the wild. Evol. Appl., 1, 342-355.

727 Arlinghaus, R., and Mehner, T. 2005. Determinants of management preferences of

728 recreational anglers in Germany: Habitat management versus fish stocking.

$729 \quad$ Limnologica, 35, 2-17.

730 Arlinghaus, R., Mehner, T., and Cowx, I.G. 2002. Reconciling traditional inland

731 fisheries management and sustainability in industrialized countries, with

732 emphasis on Europe. Fish Fish., 3, 261-316.

733 Arlinghaus, R., Cooke S.J., and Cowx I.G. 2010. Providing context to the global code

734 of practice for recreational fisheries. Fish. Manag. Ecol., 17, 146-156.

735 Ayllón, D., Almodóvar, A., Nicola, G.G., Parra, I., and Elvira B. 2012. A new

736 biological indicator to assess the ecological status of Mediterranean trout type

737 streams. Ecol. Indic., 20, 295-303.

738 Baer, J., and Brinker, A. 2010. The response of a brown trout stocks and perception of

739 anglers to cessation of brown trout stocking. Fish. Manag. Ecol., 17, 157-164. 
740 Baer, J., Blasel, K., and Diekmann, M. 2007. Benefits of repeated stocking with adult,

741 hatchery-reared brown trout, Salmo trutta, to recreational fisheries? Fish.

$742 \quad$ Manag. Ecol., 14, 51-59.

743 Baskett, M.L., and Waples, R.S. 2012. Evaluating alternative startegies for minimizing

744 unintended fitness consequences of cultured individuals on wild populations.

745 Conserv. Biol., 27, 83-94.

746 Baskett, M.L., Burgess, S.C., and Waples, R.S. 2013. Assessing strategies to minimize

747 unintended fitness consequences of aquaculture on wild condotions. Evol. Appl.,

$748 \quad 6,1090-1108$.

749 Berejikian, B.A., Johnson, T., Endicott, R.S., and Lee-Waltermire, J. 2008. Increases in

750 steelhead (Oncorhynchus mykiss) redd abundance resulting from two

751 conservation hatchery strategies in the Hamma Hamma River, Washington. Can.

752 J. Fish. Aquat. Sci., 65, 754-764.

753 Brown, C., and Day, R.L. 2002. The future of stock enhancements: lessons for hatchery 754 practice from conservation biology. Fish Fish., 3, 79-94.

755 Caudron, A., Champigneulle, A., Guyomard, R., and Largiadèr, C.R. 2011. Assessment

756 of three strategies practiced by fishery managers for restoring native brown trout

757 (Salmo trutta) populations in Northern French Alpine Streams. Ecol. Freshw.

$758 \quad$ Fish, 20, 478-491.

759 Caudron, A., Champigneulle, A., Vigier, L., Hamelet, V., and Guyomard, R. 2012.

760 Early effects of the strategies of creating a genetic refuge and direct

761 translocation for conserving and restoring populations of native brown trout.

$762 \quad$ Freshw. Biol., 57, 1702-1715

763 Christie, M.R., Marine, M.L., French, R.A., and Blouin, M.S. 2012. Genetic adaptation

764 to captivity can occur in a single generation. PNAS, 109, 238-242. 
765 Cowx, I.G., and Gerdeaux, D. 2004. The effects of fisheries management practices on

766 freshwater ecosystems. Fish. Manag. Ecol., 11, 145-151.

767 Cowx, I.G., and Van Anrooy, R. 2010. Social, economic and ecological objectives of

768 inland comercial and recreational fisheries. Fish. Manag. Ecol.,18, 89-92.

769 Cowx, I.G., Arlinghaus, R., and Cooke, S.J. 2010. Harmonizing recreational fisheries

770 and conservation objectives for aquatic biodiversity in inland waters. J. Fish

$771 \quad$ Biol., 76, 2194-2215.

772 Dieringer, D., and Schlötterer, C. 2003. Microsatellite analyser (MSA): a platform

773 independent analysis tool for large microsatellite data sets. Mol. Ecol. Notes, 3, $774 \quad 167-169$.

775 Eldridge, W.H., Myers, J.M., and Naish, K.A. 2009. Long-term changes in the fine-

776 scale population structure of coho salmon populations (Oncorhynchus kisutch)

777 subject to extensive supportive breeding. Heredity, 103, 299-309.

778 Elliott, J.M. 1989. Wild brown trout Salmo trutta: an important national and

779 international resource. Freshw. Biol., 21, 1-5.

780 Evanno, G., Regnaut, S., and Goudet, J. 2005. Detecting the number of clusters of

781 individuals using the software structure: a simulation study. Mol. Ecol. 14,

$782 \quad 2611-2620$.

783 Excoffier, L., and Lischer, H.E. L. 2010. Arlequin suite ver 3.5: A new series of

784 programs to perform population genetics analyses under Linux and Windows.

785 Mol. Ecol. Resour., 10, 564-567.

786 FAO. 1995. Code of conduct for responsible fisheries. FAO Fisheries and Aquaculture

787 Department, FAO, Rome. 41pp. Available at:

788 http://www.fao.org/docrep/005/v9878e/v9878e00.HTM. [last accessed: 28-

789 Setember-2013] 
FAO. 2008. EIFAC Code of Practice for Recreational Fisheries. EIFAC Occasional Paper, 42. 45p.

792 Ford, M.J. 2002. Selection in captivity during supportive breeding may reduce fitness in the wild. Conserv. Biol., 16, 815-825.

794 Fraser, D.J. 2008. How well can captive breeding programs conserve biodiversity? A review of salmonids. Evol. Appl., 1, 535-586.

Fraser, D.J., Weir, L.K., Bernatchez, L., Hansen, M.M., and Taylor, E.B. 2011. Extent and scale of local adaptation in salmonid fishes: review and meta-analysis. Heredity, 106, 404-420.

Freyhof, J., and Brooks, E. 2011. European Red List of Freshwater Fishes. Luxembourg: Publications Office of the European Union. 60p. available at: http://data.iucn.org/dbtwwpd/commande/downpdf.aspx?id=12069andurl=http://www.iucn.org/dbtwwpd/edocs/RL-4-015.pdf [last accessed: 28-January-2013]

García de Jalón, D., Montes, C., Barceló, E., Casado, C., and Menes, F. 1988. Effects of

807 García de Jalón, D., Mayo, M., and Molles, M.C. 1996. Characterization of Spanish 808 Pyrenean stream habitat: Relationships between fish communities and their 809 habitat. Regul. Rivers, 12, 305-316.

810 García-Marín, J.L., Sanz, N, and Pla, C. 1998. Proportions of native and introduced 811 brown trout in adjacent fished and unfished Spanish rivers. Conserv. Biol. 12, $812 \quad 313-319$.

813 Gayanilo, F.C.Jr., Sparre, P., and Pauly, D. 2005. FAO-ICLARM Stock Assessment 814 Tools II (FiSAT II). Revised version. User's guide. FAO Computerized 

Information Series (Fisheries).No.8, Revised version. Rome, FAO. 2005. 168 p. [FISAT II available from: http://www.fao.org/fishery/topic/16072/en, last accessed 30-Setember-2013]

Goudet, J. 1995. FSTAT Version 1.2: a computer program to calculate F-statistics. J. Heredity 86: 485-486. [ FSTAT 2.9.3.2 available from: http://www2.unil.ch/popgen/softwares/fstat.htm, last accessed: 28-January-

Guillaume, F., and Rougemont, J. 2006. Nemo: an evolutionary and population genetics

Guo, S.W., and Thompson, E.A. 1992. Performing the exact test of Hardy-Weinberg programming framework. Bioinformatics 22:2556-2557. proportions for multiple alleles. Biometrics, 48, 361-372.

Hari, R. E., Livingstone, D. M., Siber, R., Burkhardt-Holm, P., and Guttinger, H. 2006. Consequences of climatic change for water temperature and brown trout populations in Alpine rivers and streams. Glob. Change Biol., 12, 10-26.

Hansen, M.M., Skaala, O., Jensen, L.F., Bekkevold, D., and Mensberg, K.L. 2007. Gene flow, effective population size and selection at major histocompatibility complex genes: brown trout in the Hardanger Fjord, Norway. Mol. Ecol., 16, 1413-1425.

Hansen, M.M., Fraser, D.J., Meier, K., and Mensberg, K.L. 2009. Sixty years of anthropogenic pressure: a spatio-temporal genetic analysis of brown trout populations subject to stocking and population declines. Mol. Ecol., 18, 25492562. 
840 Hansen, M.M., Meier, K., and Mensberg, K.L. 2010. Identifying footprints of selection

841 in stocked brown trout populations: a spatio-temporal approach. Mol. Ecol., 19,

$842 \quad 1787-1800$.

843 Hess, M.A., Rabe, C.D., Vogel, J.L., Stephenson, J., Nelson, D.D., and Narum, S.R.

844 2012. Supportive breeding boosts natural population abundance with minimal

845 negative impacts on fitness of wild population of Chinook salmon. Mol. Ecol.,

$846 \quad 21,5236-5250$.

847 Hoban, S., Bertorelle, G, and Gaggiotti, E. 2012. Computer simulations: tools for

848 population and evolutionary genetics. Nature Review, Genetics, 13:110-122.

849 Jensen, L.F., Hansen, M.M., Pertoldi, C., Holdensgaard, G., Mensberg, K.-L. D., and

850 Loeschcke, V. 2008a. Local adaptation in brown trout early life-history traits:

851 implications for climate change adaptability. Proc. R. Soc. B, 275, 2859-2868.

852 Jensen, L.F., Hansen, M.M., Mensberg, K.L., and Loeschcke, V. 2008b. Spatially and

853 temporally fluctuating selection at non-MHC immune genes: evidence from

854 TAP polymorphism in populations of brown trout (Salmo trutta, L.). Heredity,

$855 \quad 100,79-81$.

856 Jug, T., Berrebi, P., and Snoj, A. 2005 Distribution of non-native trout in Slovenia and

857 their introgression with native trout populations as observed through

858 microsatellite DNA analysis. Biol. Conserv., 123, 381-388.

859 Keller, I., Taverna, A., and Seehausen, O. 2011. Evidence of neutral and adaptive

860 genetic divergence between European trout populations sampled along

861 altitudinal gradients. Mol. Ecol., 20, 1888-1904.

862 Knouft, J.H., and Spotila, J.R. 2002. Assessment of movements of resident stream

863 brown trout, Salmo trutta L., among contiguous sections of stream. Ecol.

$864 \quad$ Freshw. Fish, 11, 85-91. 
865 Kottelat, M., and Freyhof, J, 2007. Handbook of European freshwater fishes.

866 Publications Kottelat, Cornol, Switzerland. 646 p.

867 Laikre, L., Schwartz, M.K., Waples, R.S., Ryman, N., and The GeM Working Group.

868 2010. Compromising genetic diversity in the wild: unmonitored large-scale

869 release of plants and animals. Trends Ecol. Evol., 25, 520-529.

870 Laikre, L., and Ryman, N. 1996. Effects on intraspecific biodiversity from harvesting

871 and enhancing natural populations. AMBIO 25, $504-509$.

872 Lelek, A. 1980. Threatened freshwater fishes in Europe. Nature and Environment Series

873 No. 18. Council of Europe, Strasbourg.269pp.

874 Lewin, W.-C., Arlinghaus, R., and Mehner, T. 2006. Documented and potential

875 biological impacts of recreational fishing: Insights for management and

876 conservation. Rev. Fish. Sci., 14,305-367.

877 Lobón-Cerviá, J., Montañés, C., and de Sostoa, A. 1986. Reproductive ecology and

878 growth of a population of brown trout (Salmo trutta L.) in an aquifer-fed stream

879 of Old Castile. Hydrobiologia, 135, 81-94.

880 Lobón-Cerviá, J., Utrilla, C., Rincón, P., and Amezcua, F. 1997. Environmentally

881 induced spatio-temporal variations in the fecundity of brown trout Salmo trutta

882 L.: trade-offs between egg size and number. Freshw. Biol., 38, 277-288.

883 Marzano, F.N., Corradi,N., Papa, R., Tagliavini J., and Gandolfi, G. 2003. Molecular

884 Evidence for Introgression and Loss of Genetic Variability in Salmo (trutta)

885 macrostigma as a Result of Massive Restocking of Apennine Populations

886 (Northern and Central Italy). Environ. Biol. Fish., 68, 349-356.

887 Meier, K., Hansen, M.M., Bekkevold, D., Skaala, Ø., and Mensberg, K.-L. D. 2011. An

888 assessment of the spatial scale of local adaptation in brown trout (Salmo trutta

889 L.): footprints of selection at microsatellite DNA loci. Hereity, 106, 488-499. 
890 Mills, L.S., and Allendorf, F.W. 1996. The One-Migrant-per-Generation Rule in

891 Conservation and Management. Conserv. Biol., 10, 1509-1518.

892 Naish, K.A., Taylor, J.E. III, Levin, P.S., Quinn, T.P., Winton, J.R., Huppert, D., and

893 Hilborn, R. 2007. An Evaluation of the Effects of Conservation and Fishery

894 Enhancement Hatcheries on Wild Populations of Salmon. Adv. Mar. Biol., 53,

$895 \quad 61-194$.

896 Nei, M. 1987. Molecular evolutionary genetics. Columbia University Press, New York.

$897 \quad 271 \mathrm{pp}$.

898 Nicola, G., Almodóvar, A., Jonsson, B., and Elvira B. 2008. Recruitment variability of

899 resident brown trout in peripheral populations from southern Europe. Freshw.

$900 \quad$ Biol., 53, 2364-2374.

901 Nicola, G.G., Almodóvar, A., and Elvira, E. 2009. Influence of hydrologic attributes on

902 brown trout recruitment in low-latitude range margins. Oecologia, 160, 515-524.

903 Nielsen, E.E., Bach, L.A., and Kotlicki, P. 2006. HYBRIDLAB (version 1.0): a

$904 \quad$ program for generating simulated hybrids from population samples. Mol. Ecol.

$905 \quad$ Notes, 6, 971-973.

906 Parra, I., Almodóvar, A., Nicola, G.G., and Elvira, B. 2009. Latitudinal and altitudinal

907 growth pattern of brown trout Salmo trutta at different spatial and temporal

908 scales. J. Fish Biol., 74, 2355-2373.

909 Perrier, C., Baglinière, J.-L., and Evanno, G. 2013. Understanding admixture patterns in

910 supplemented populations: a case study combining molecular analyses and

911 temporally explicit simulations in Atlantic salmon. Evol Appl., 6, 218-230.

912 Poteaux, C., Bonhomme, F., and Berrebi, P. 1999. Microsatellite polymorphism and

913 genetic impact of restocking in Mediterranean brown trout (Salmo trutta L.).

$914 \quad$ Heredity, 82, 645-653. 
915 Pritchard, J.K., Stephens, M., and Donnelly, P. 2000. Inference of population structure

916 using multilocus genotype data. Genetics, 155, 945-959.

917 Raymond, M., and Rousset, F. 1995. GENEPOP (ver.3.3): a population genetics

918 software for exact test and ecumenism. J. Hered., 86, 248-249.

919 Rhymer, J.M., and Simberloff, D. 1996. Extinction by Hybridization and introgression.

920 Annu. Rev. Ecol. Syst., 27, 83-109

921 Ryman, N., and Laikre, L. 1991. Effects of Supportive Breeding on the Genetically

922 Effective Population Size. Conserv. Biol., 5, 325-329.

923 Rocaspana, R., Cia, I., Arévalo, J. A., Escué, A., Pou, J., and Pou, C. 2006. Estudi de

924 la mida mitjana de la truita en les zones d'alta muntanya de Catalunya.

925 Departament de Medi Ambient i Habitatge, Generalitat de Catalunya.

926 http://www20.gencat.cat/docs/dmah/Home/Ambits\%20dactuacio/Medi\%20natur

927 al/Caca $\% 20 \mathrm{i} \% 20$ pesca $\% 20$ continental/Pesca $\% 20$ continental/Estudis $\% 20 \mathrm{i} \% 20 \mathrm{di}$

928 agnosis/43 138255.pdf [last accessed: 28-January-2013]

929 Ruzzante, D. E., Hansen, M. M., and Meldrup, D. 2001. Distribution of individual

930 inbreeding coefficients, relatedness and influence of stocking on native

931 anadromous brown trout (Salmo trutta) population structure. Mol. Ecol., 10,

$932 \quad 2107-2128$.

933 Sanz, N., García-Marín, J.L., and Pla, C. 2002. Managing fish populations under mosaic

934 relationships. The case of brown trout (Salmo trutta) in peripheral

935 Mediterrranean populations. Conserv. Genet., 3, 385-400.

936 Sanz, N., Cortey, M., Pla, C., and García-Marín, J.L. 2006. Hatchery introgression blurs

937 ancient hybridization between brown trout (Salmo trutta) lineages as indicated

938 by complementary allozymes and mtDNA markers. Biol. Conserv., 130, 278-

939289. 
940 Sanz, N., Araguas, R.M., Fernández, R., Vera, M., and García-Marín, J.L. 2009.

941 Efficiency of markers and methods for detecting hybrids and introgression in 942 stocked populations. Conserv. Genet., 10, 225-236.

943 Satake, A., and Araki, H. 2012. Stocking of captive-bred fish can cause long-term 944 population decline and gene pool replacement: predictions from a population 945 dynamics model incorporating density-dependent mortality. Theor. Ecol., 5, $946 \quad 283-296$.

947 Stelkens, B., Pompini, M., and Wedekind, C. 2012. Testing for local adaptation in 948 brown trout using reciprocal transplants. BMC Evol. Biol. 12, 247.

949 Van Doornik, D.M., Berejikian, B.A., Campbell, L.A., and Volk, E.C. 2010. The effect 950 of a supplementation program on the genetic and life history characteristics of an 951 Oncorhynchus mykiss population. Can. J. Fish. Aquat. Sci., 67, 1449-1458.

952 Van Oosterhout, C., Hutchinson, W.F., Wills, D.P.M., and Shipley, P. 2004. MICRO-

953 CHECKER: software for identifying and correcting genotyping errors in 954 microsatellite data. Mol. Ecol. Notes, 4, 535-538

955 Van Poorten, B. T., Arlinghaus, R., Daedlow, K., and Haertel-Borer, S.S. 2011. Social-

956 ecological interactions, management panaceas, and the future of wild fish

957 populations. PNAS, 108, 12554-12559.

958 Vera, M., Sanz, N., Hansen, M.M., Almodóvar, A., and García-Marín, J.-L. 2010.

959 Population and family structure of brown trout, Salmo trutta, in a Mediterranean

960 stream. Mar. Freshw. Res., 61, 672-681.

961 Vera, M., Garcia-Marin, J.L., Martinez, P., Araguas, R.M., and Bouza, C. 2013.

962 Identification and conservation of remnant genetic resources of brown trout in 963 relict populations from Western Mediterranean streams. Hydrobiologia, 707, 29$964 \quad 45$. 
965 Vøllestad, L.A., Serbezov, D., Bass, A., Bernatchez, L., Olsen, E.M., and Taugbøl, A. 966 2012. Small-scale dispersal and population structure in stream-living brown 967 trout (Salmo trutta) inferred by mark-recapture, pedigree reconstruction, and 968 population genetics. Can. J. Fish. Aquat. Sci., 69, 1513-1524.

969 Wang, J., and Ryman, N. 2001. Genetic effects of multiple generations of supportive $970 \quad$ breeding. Conserv. Biol., 15, 1619-1631.

971 Waples, R.S., and Do, C. 2008. LDNE: a program for estimating effective population 972 size from data on linkage disequilibrium. Mol. Ecol. Resour., 8, 753-756.

973 Waples, R.S., and Do, C. 2010. Linkage disequilibrium estimates of contemporary $\mathrm{Ne}$ 974 using highly variable genetic markers: a largely untapped resource for applied 975 conservation and evolution. Evol. Appl., 3, 244-262.

976 Waples, R.S., and England, P.R. 2011. Estimating Contemporary Effective Population 977 Size on the Basis of Linkage Disequilibrium in the Face of Migration. Genetics, $978 \quad 189,633-644$.

979 Weir, B.S., and Cockerham, C.C. 1984. Estimating F-statistics for the analysis of $980 \quad$ population structure. Evolution, 38, 1358-1370. 


\section{Figure Captions}

983

984

985 Fig. 1. Geographic locations of the brown trout collections and the two hatcheries

986 (HAT) in the study region. Location codes are defined in Table 1.

987

988 Fig. 2. Current individual sample relationships indicated by STRUCTURE analysis

989 considering 2, 3, 4 and 5 genetic groups. Each individual is represented by a vertical bar

990 partitioned into segments according to the proportion of the genome assigned to each of

991 the identified clusters. Location codes are defined in Table 1.

992

993 Fig. 3. Multidimensional scaling (MDS) plots of population genetic structure from

994 captured collections (2006 collections), and from simulations without (drift), and with

995 supplementation by current foreign or native stocks. Circles represent Noguera Pallaresa

996 locations, triangles Noguera Ribagorzana, and Coastal management unit is represented

997 by squares. Location codes are defined in Table 1. 
Table 1. Genetic diversity in study brown trout locations. $N$ : sample size, Adult: percentage of fish older than $2+$ at time of capture (class $0+$ excluded), $A_{R}$ : Allelic richness per population, $H_{O}$ : mean direct count heterozygosity, $H_{E}$ : mean unbiased expected heterozygosity, $q$ : estimate average proportion of foreign hatchery stock ancestry, $K$ : number of genetically homogenous units in the sample, $N e$ : estimated effective population size (CI: Jackknife on loci 95\% Confidence Interval), GR: Genetic refuge area. Very large effective sizes are indicated when negative $\mathrm{Ne}$ was obtained from LDNe calculations (Waples and Do 2010). In bold, locations used as source of the native stocks (see text)

\begin{tabular}{lllllllllllll}
\hline River & Location & stream & $\boldsymbol{N}$ & Adult (>2+) & $A_{R}$ & $\boldsymbol{H}_{\boldsymbol{o}}$ & $\boldsymbol{H}_{\boldsymbol{E}}$ & $\boldsymbol{q}$ & $\boldsymbol{K}$ & Ne (CI) & $\boldsymbol{G R}$ \\
\hline \multirow{2}{*}{ N. Pallaresa } & Palomera (PL) & Vallfarrera & 55 & 34.7 & 6.51 & 0.654 & 0.664 & 0.004 & 1 & $281.0(99.6-\alpha)$ & Yes \\
& Ermita (ER) & Vallfarrera & 46 & 36.4 & 6.73 & 0.683 & 0.663 & 0.003 & 1 & $293.7(88.7-\alpha)$ & Yes \\
& Tor (TOR) & Tor & 43 & 8.5 & 4.89 & 0.380 & 0.421 & 0.034 & 2 & $27.5(10.4-152.2)$ & No \\
& Ainet (AC) & Cardos & 71 & 35.0 & 7.31 & 0.665 & 0.666 & 0.018 & 1 & Very large (243.9- $\alpha)$ & No \\
& Manyanet (MY) & Flamisell & 104 & 8.5 & 4.86 & 0.577 & 0.594 & 0.007 & 1 & $227.1(109.4-1877.4)$ & Yes \\
& Filià (FI) & Flamisell & 46 & 35.0 & 8.40 & 0.744 & 0.769 & 0.300 & 2 & $18.7(15.8-22.2)$ & Yes \\
\hline \multirow{2}{*}{ N. Ribagorzana } & Conangles (CO) & Ribagorçana & 45 & 20.5 & 5.52 & 0.457 & 0.484 & 0.045 & 1 & $31.0(12.8-149.1)$ & Yes \\
& Cavallers (CV) & Noguera Tor & 55 & 34.5 & 5.18 & 0.513 & 0.536 & 0.020 & 1 & $47.0(27.3-101.8)$ & Yes \\
& Nicolau (NI) & St. Nicolau & 43 & 13.5 & 5.56 & 0.530 & 0.555 & 0.040 & 1 & $107.4(35.6-\alpha)$ & No \\
& Erta (ERT) & Erta & 72 & 14.9 & 3.58 & 0.431 & 0.455 & 0.003 & 1 & $66.7(20.7-\alpha)$ & Yes \\
\hline Ter & Vallter (TE) & Ter & 65 & 56.9 & 3.23 & 0.379 & 0.393 & 0.002 & 1 & $61.2(24.0-877.7)$ & Yes \\
& Núria (NU) & Freser & 155 & 10.1 & 4.67 & 0.489 & 0.529 & 0.016 & 2 & $53.0(27.0-118.5)$ & Yes \\
\hline Llobregat & Riutort (RT) & Llobregat & 56 & 29.1 & 6.22 & 0.623 & 0.630 & 0.300 & 2 & $30.6(19.2-55.3)$ & No \\
\hline Hatchery & HAT1 & Foreign stock & 96 & - & 7.78 & 0.666 & 0.682 & - & 1 & $66.8(52.7-87.4)$ & - \\
\hline
\end{tabular}


Table 2. Pairwise genetic differentiation $\left(F_{S T}\right.$ values, Weir and Cockerham, 1984) between brown trout captured in study locations and the current foreign stock. Location code as in Table $1 .{ }^{*} P<0.05$

\begin{tabular}{|c|c|c|c|c|c|c|c|c|c|c|c|c|c|}
\hline & PL & ER & TOR & $\mathbf{A C}$ & MY & FI & $\mathrm{CO}$ & $\mathrm{CV}$ & NI & ERT & TE & $\mathbf{N U}$ & RT \\
\hline ER & 0.003 & & & & & & & & & & & & \\
\hline TOR & $0.192 *$ & $0.175^{*}$ & & & & & & & & & & & \\
\hline $\mathbf{A C}$ & $0.032 *$ & $0.025^{*}$ & $0.183^{*}$ & & & & & & & & & & \\
\hline MY & $0.190^{*}$ & $0.187^{*}$ & $0.329 *$ & $0.171^{*}$ & & & & & & & & & \\
\hline FI & $0.121 *$ & $0.122 *$ & $0.266^{*}$ & $0.108^{*}$ & $0.158^{*}$ & & & & & & & & \\
\hline $\mathrm{CO}$ & $0.294^{*}$ & $0.281 *$ & $0.425^{*}$ & $0.253 *$ & $0.285^{*}$ & $0.247 *$ & & & & & & & \\
\hline $\mathrm{CV}$ & $0.193 *$ & $0.202 *$ & $0.273^{*}$ & $0.226^{*}$ & $0.312 *$ & $0.204 *$ & $0.334^{*}$ & & & & & & \\
\hline NI & $0.203^{*}$ & $0.198 *$ & $0.392 *$ & $0.221^{*}$ & $0.250 *$ & $0.188^{*}$ & $0.331^{*}$ & $0.275^{*}$ & & & & & \\
\hline ERT & $0.299 *$ & $0.324^{*}$ & $0.463^{*}$ & $0.310^{*}$ & $0.186^{*}$ & $0.264 *$ & $0.454^{*}$ & $0.405^{*}$ & $0.390^{*}$ & & & & \\
\hline TE & $0.298^{*}$ & $0.323^{*}$ & $0.419^{*}$ & $0.335^{*}$ & $0.379 *$ & $0.348 *$ & $0.475^{*}$ & $0.379 *$ & $0.437 *$ & $0.421 *$ & & & \\
\hline NU & $0.217^{*}$ & $0.199 *$ & $0.308^{*}$ & $0.206^{*}$ & $0.291 *$ & $0.261 *$ & $0.378^{*}$ & $0.329 *$ & $0.319 *$ & $0.409^{*}$ & $0.354^{*}$ & & \\
\hline RT & $0.260 *$ & $0.264^{*}$ & $0.397 *$ & $0.259 *$ & $0.305^{*}$ & $0.173 *$ & $0.364 *$ & $0.329 *$ & $0.344^{*}$ & $0.288^{*}$ & $0.391 *$ & $0.353^{*}$ & \\
\hline $\begin{array}{c}\text { Foreign } \\
\text { stock }\end{array}$ & $0.275^{*}$ & $0.278^{*}$ & $0.390^{*}$ & $0.261^{*}$ & $0.309 *$ & $0.116^{*}$ & $0.317^{*}$ & $0.297 *$ & $0.298 *$ & $0.377^{*}$ & $0.426^{*}$ & $0.366^{*}$ & $0.190 *$ \\
\hline
\end{tabular}


Table 3. Gene diversity analyses and population structure in the study region using current genotypes, or simulated after 100 generations in scenarios without (Drift), and with supplementation by native stocks, or foreign stock. $A_{R}$ : Average allelic richness. Total gene diversity $\left(H_{T}\right)$ was partitioned in diversity within locations $\left(H_{S}\right)$ and differentiation between locations $\left(G_{S T}\right)$. The per cent of population differentiation assigned to divergence among samples within $(S C)$, and among $(C T)$ hydrological management units was estimated according to AMOVA analyses. $\mathrm{N}$ : effective population size used in simulations; $\mathrm{t}$ : indicated accumulated simulated generations. * Significant $(P<0.05)$ comparison relative to generation $0(\mathrm{G} 0)$ values in gene diversity analysis.

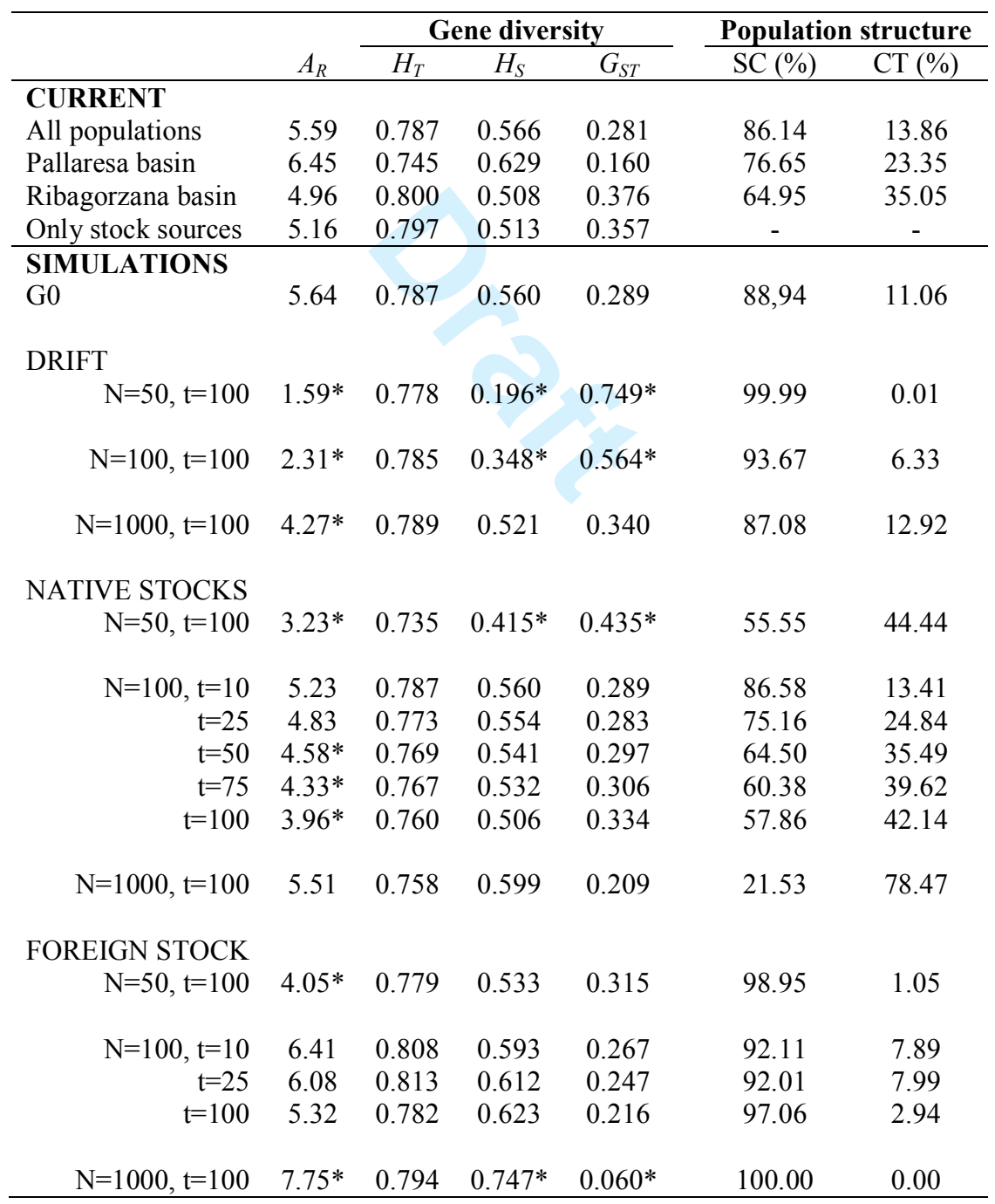


Table 4. Diversity levels in each location and stock at simulated Generations 0 and 100, in scenarios without (drift), and with supplementation by native stocks or by a foreign stock. $H_{E}$ : expected heterozygosis ( $A_{R}$, Average allele richness). $F_{S T}$ : estimated genetic divergence between simulated Generation 0 and 100 at each location and stock. In bold, source location for each simulated native stocks. Effective population sizes of 100 fish for wild locations and 1000 fish for stocks. ${ }^{*} P<0.05$.

\begin{tabular}{|c|c|c|c|c|c|c|c|}
\hline & \multicolumn{4}{|c|}{$H_{E}\left(A_{R}\right)$} & \multirow{2}{*}{\multicolumn{3}{|c|}{$\begin{array}{c}F_{S T} \\
0-100\end{array}$}} \\
\hline & \multirow[b]{2}{*}{ GEN 0} & \multicolumn{3}{|c|}{ GEN 100} & & & \\
\hline & & Drift & Native & Foreign & Drift & Native & Foreign \\
\hline \multicolumn{8}{|l|}{ Noguera Pallaresa } \\
\hline Palomera & $0.654(6.67)$ & $0.312(2.44)$ & $0.565(4.44)$ & $0.606(5.44)$ & $0.223^{*}$ & $0.136^{*}$ & $0.275^{*}$ \\
\hline Ermita & $0.646(6.56)$ & $0.402(2.78)$ & $0.534(4.22)$ & $0.656(5.67)$ & $0.170^{*}$ & $0.081 *$ & $0.229^{*}$ \\
\hline Tor & $0.413(4.67)$ & $0.299(1.78)$ & $0.471(4.00)$ & $0.618(5.44)$ & $0.226^{*}$ & $0.185^{*}$ & $0.267^{*}$ \\
\hline Ainet & $0.642(7.78)$ & $0.480(2.67)$ & $0.447(4.33)$ & $0.629(5.44)$ & $0.220^{*}$ & $0.129 *$ & $0.146^{*}$ \\
\hline Manyanet & $0.591(5.00)$ & $0.382(2.67)$ & $0.598(5.22)$ & $0.623(5.44)$ & $0.116^{*}$ & $0.132 *$ & $0.236^{*}$ \\
\hline Filià & $0.761(8.22)$ & $0.378(2.89)$ & $0.592(5.00)$ & $0.597(5.33)$ & $0.230^{*}$ & $0.135^{*}$ & $0.142 *$ \\
\hline \multicolumn{8}{|l|}{ Noguera Ribagorzana } \\
\hline Conangles & $0.468(5.11)$ & $0.269(2.00)$ & $0.434(3.56)$ & $0.641(5.33)$ & $0.140^{*}$ & $0.057^{*}$ & $0.257^{*}$ \\
\hline Cavallers & $0.541(5.22)$ & $0.394(2.33)$ & $0.549(4.22)$ & $0.653(5.67)$ & $0.164 *$ & $0.149^{*}$ & $0.151^{*}$ \\
\hline Nicolau & $0.558(5.56)$ & $0.261(2.00)$ & $0.519(3.89)$ & $0.588(5.33)$ & $0.220^{*}$ & $0.295^{*}$ & $0.265^{*}$ \\
\hline Erta & $0.451(3.78)$ & $0.307(1.78)$ & $0.541(3.78)$ & $0.574(4.56)$ & $0.203^{*}$ & $0.277 *$ & $0.251^{*}$ \\
\hline \multicolumn{8}{|l|}{ Coastal Basins } \\
\hline Vallter & $0.392(3.00)$ & $0.225(1.67)$ & $0.284(2.67)$ & $0.667(5.44)$ & $0.192 *$ & $0.140^{*}$ & $0.249^{*}$ \\
\hline Nuria & $0.537(5.67)$ & $0.463(2.67)$ & $0.552(2.89)$ & $0.587(5.11)$ & $0.202 *$ & $0.166^{*}$ & $0.256^{*}$ \\
\hline Riutort & $0.629(6.11)$ & $0.349(2.44)$ & $0.496(3.22)$ & $0.665(4.89)$ & $0.181 *$ & $0.253 *$ & $0.163^{*}$ \\
\hline \multicolumn{8}{|l|}{ Simulated Stocks } \\
\hline Pallaresa basin & $0.653(6.78)$ & - & $0.631(5.50)$ & - & - & $0.024 *$ & - \\
\hline Ribagorzana basin & $0.480(5.56)$ & - & $0.443(3.78)$ & - & - & $0.045^{*}$ & - \\
\hline Coastal basins & $0.392(3.33)$ & - & $0.355(3.00)$ & - & - & $0.021 *$ & - \\
\hline Foreign stock & $0.679(7.78)$ & - & - & $0.638(6.22)$ & - & - & $0.031^{*}$ \\
\hline
\end{tabular}


Table 5. Estimate ancestries in each populations after 100 generations in scenarios without (Drift) and with supplementation with native stocks, and $\mathrm{Ne}$ of 100 fish. Np: average remaining ancestry of the local gene pool; Ss: average ancestry of the simulated native stock. In each basin, location in bold was the source of the native stock.

\begin{tabular}{|c|c|c|c|c|}
\hline \multirow[b]{2}{*}{ Basin/Location } & \multicolumn{2}{|c|}{ Drift } & \multicolumn{2}{|c|}{ Supplementation } \\
\hline & $\mathbf{N p}$ & Ss & Np & Ss \\
\hline \multicolumn{5}{|l|}{ Noguera Pallaresa } \\
\hline Palomera & 0.983 & 0.957 & 0.890 & 0.934 \\
\hline Ermita & 0.976 & 0.957 & 0.975 & 0.953 \\
\hline Tor & 0.950 & 0.867 & 0.778 & 0.926 \\
\hline Ainet & 0.795 & 0.675 & 0.862 & 0.961 \\
\hline Manyanet & 0.966 & 0.580 & 0.653 & 0.781 \\
\hline Filià & 0.966 & 0.197 & 0.845 & 0.675 \\
\hline \multicolumn{5}{|c|}{ Noguera Ribagorzana } \\
\hline Conangles & 0.993 & 0.927 & 0.981 & 0.905 \\
\hline Cavallers & 0.895 & 0.407 & 0.675 & 0.635 \\
\hline Nicolau & 0.935 & 0.227 & 0.431 & 0.571 \\
\hline Erta & 0.956 & 0.131 & 0.397 & 0.512 \\
\hline \multicolumn{5}{|l|}{ Coastal basins } \\
\hline Vallter & 0.989 & 0.961 & 0.986 & 0.959 \\
\hline Nuria & 0.911 & 0.624 & 0.927 & 0.705 \\
\hline Riutort & 0.940 & 0.127 & 0.429 & 0.668 \\
\hline
\end{tabular}




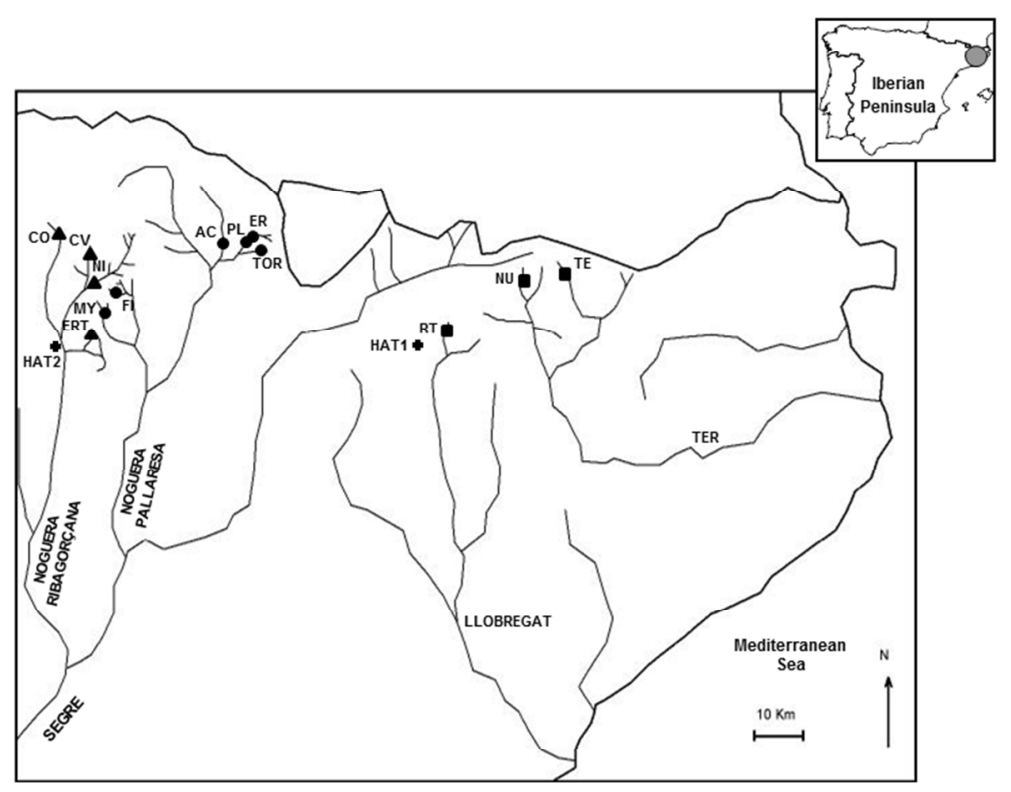

Fig. 1. Geographic locations of the brown trout collections and the two hatcheries (HAT) in the study region. Location codes are defined in Table 1.

$254 \times 190 \mathrm{~mm}(96 \times 96 \mathrm{DPI})$ 


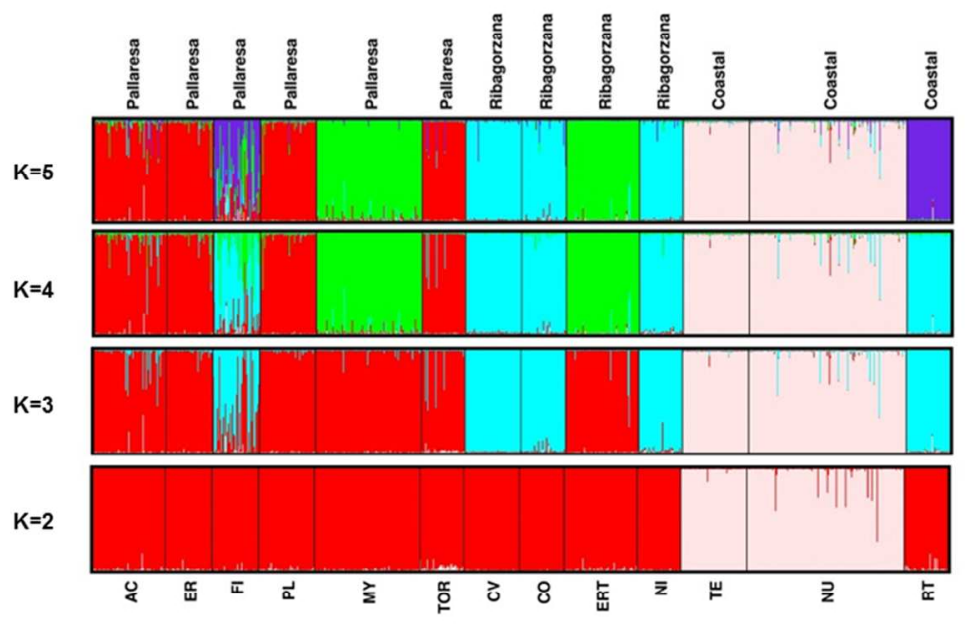

Fig. 2. Current individual sample relationships indicated by STRUCTURE analysis considering 2, 3, 4 and 5 genetic groups. Each individual is represented by a vertical bar partitioned into segments according to the proportion of the genome assigned to each of the identified clusters. Location codes are defined in Table 1. $254 \times 190 \mathrm{~mm}(96 \times 96 \mathrm{DPI})$ 

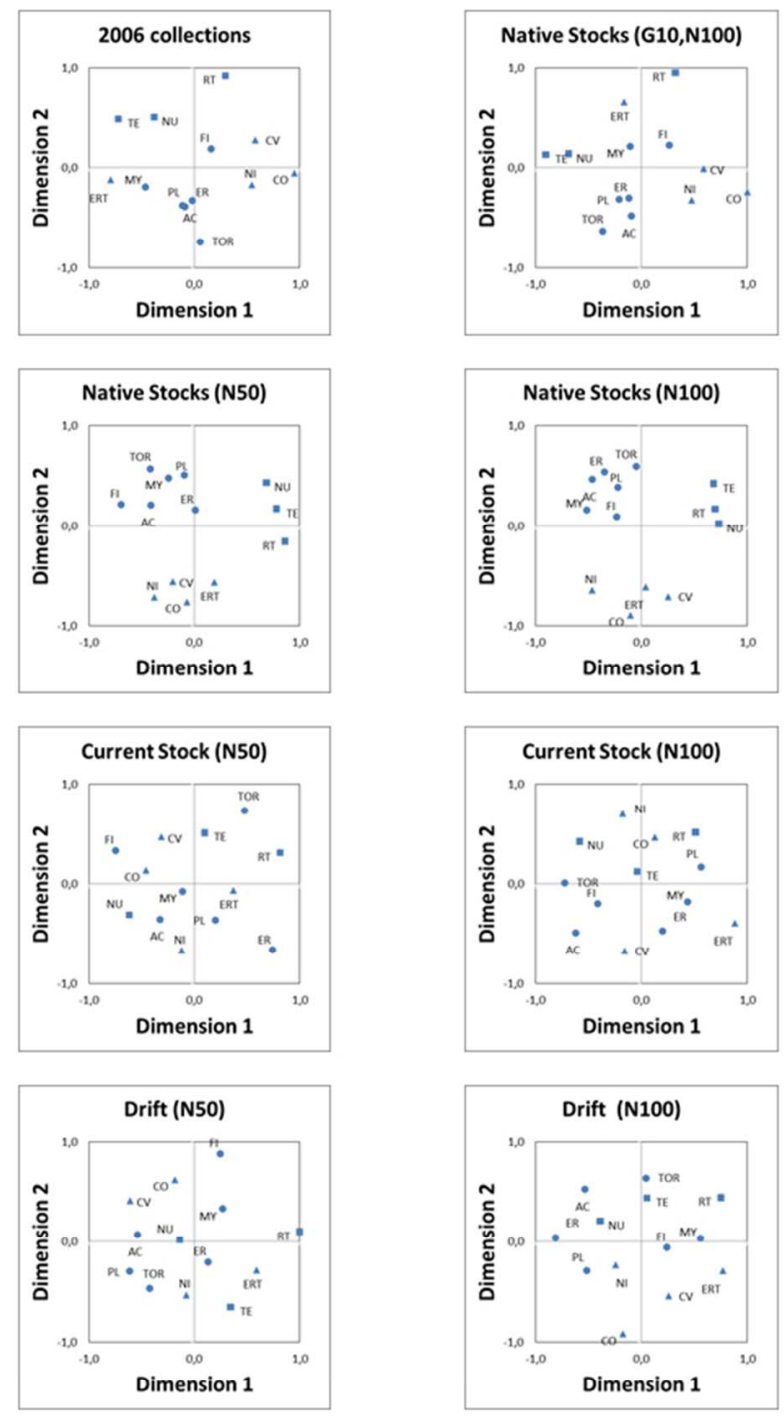

Multidimensional scaling (MDS) plots of population genetic structure from captured collections (2006 collections), and from simulations without (drift), and with supplementation by current exogenous or native stocks. Squares represent Coastal management unit, circles Noguera Pallaresa, and Noguera Ribagorçana is represented by triangles. Locality codes are defined in Table 1.

$190 \times 254 \mathrm{~mm}(96 \times 96 \mathrm{DPI})$ 